\title{
A Glycoprotein in Cardiac Conducting Tissue
}

\author{
D. J. GEE \\ From the Department of Forensic Medicine, University of Leeds
}

During a histological study of cardiac conducting tissue, intended to detect changes responsible for unexpected sudden death, attention was diverted to histochemical reactions which demonstrated the presence of a substance within the cells, which is a complex, apparently a glycoprotein. The author has not been able to discover any published report of this.

The significance of the observation was not determined, but certain causative factors have been excluded.

\section{Method AND Material}

This study was based on a series of 94 unselected coroners' necropsies, where death was due to one of a variety of causes, e.g. heart disease, accident, poisoning, etc., and a second series of 97 which included only cases of death from heart disease, mainly coronary atheroma.

Blocks of tissue containing the conducting system were removed by the method described by Lumb and Shacklett (1960). Each block was divided into four portions which were fixed in formalin, embedded in paraffin wax, and sectioned in the usual manner.

Sections were stained by haemalum and eosin, and by periodic acid-Schiff (PAS). After the PAS positive material had been determined, serial sections from some of the blocks of tissue which contained the material were examined by the methods described by Pearse (1960) for the identification of PAS positive material in histological sections. Sections were stained with Sudan black B, with Millon's reagent, with toluidine blue for metachromasia, and by the method for determining the methylene blue extinction.

\section{RESULTS}

The original purpose of using the PAS stain was to demonstrate early infarction. This object was not achieved, but it was frequently found that many cells of the conducting tissue contained PAS positive material. Where the cells were cut in cross-section, it appeared to be in the form of large oval granules, up to $6 \mu$ in diameter, present either singly or in

Received January 9, 1969. multiple, up to 10 granules, in the vacuole in the centre of the cell (Fig. 1).

Within cells cut in longitudinal section the material occurred in the form of rods. The perinuclear pigment granules, which are also PAS positive, were quite distinct from this material.

In some of the hearts examined the material was scarce, while in others it was present in large amounts, when almost all the cells contained one or more granules. Where the material was scarce it was most readily detected in the bundle or branches, and was least apparent in the AV node.

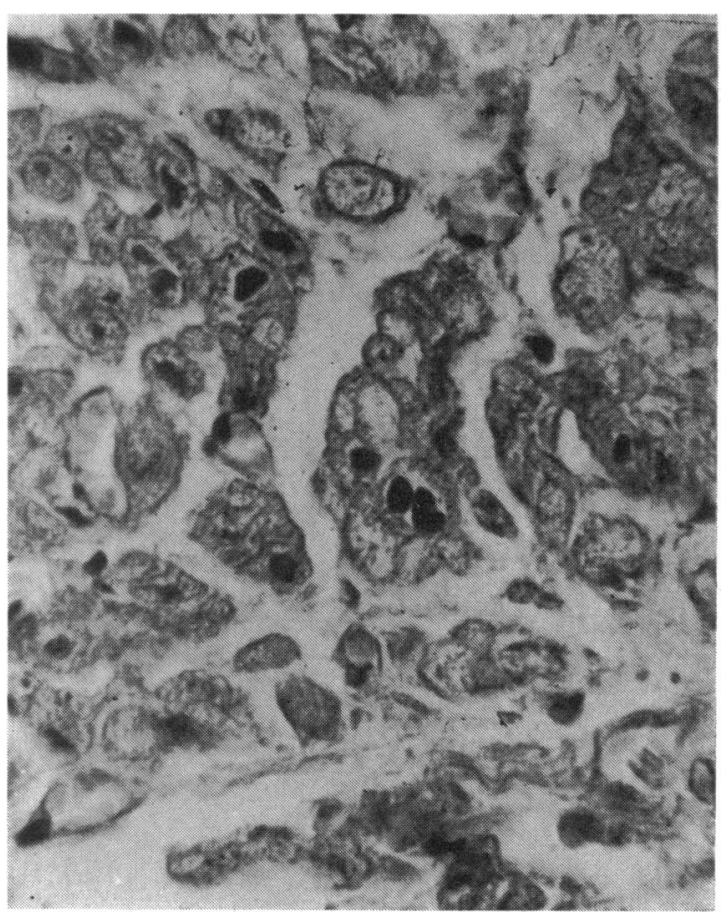

FIG. 1.-PAS positive granules within cells of cardiac conducting tissue (PAS. $\times 230$.) 
An early presumption that the material was glycogen was disproved by the fact that it was not removed by digestion with diastase (from saliva), and that it was even present in tissue taken at necropsy several days after death, notwithstanding early putrefaction of the body. The material contained protein since Millon's test was positive. It did not stain with Sudan black B, and so did not appear to be a lipid. No metachromasia was exhibited with toluidine blue, and the methylene blue extinction was at approximately $p H 7$. The material was unstained with Bismark brown. The tentative conclusion reached, therefore, was that this substance was either a glycoprotein, or a protein-carbohydrate complex.

\section{Mode of Production}

The possibility that this was an artefact, produced during the technical processes, seems unlikely since it was present in 56 per cent of the series of 94 unselected hearts and in 73 per cent of the second series of 97 selected hearts. If an artefact, the material should have been present in all the tissues examined, since the technique was the same in all cases. Moreover, in a few additional cases, where the tissue was fixed in alcohol instead of formalin, the material was also present.

TABLE

\begin{tabular}{|c|c|c|}
\hline \multirow{2}{*}{$\begin{array}{l}\text { Interval between } \\
\text { death and } \\
\text { necropsy }\end{array}$} & \multicolumn{2}{|c|}{ Intracellular glycoprotein } \\
\hline & Present & Absent \\
\hline $\begin{array}{l}<1 \text { day } \\
1 \text { day } \\
2 \text { days or more }\end{array}$ & $\begin{array}{r}4 \\
29 \\
7\end{array}$ & $\begin{array}{r}5 \\
22 \\
6\end{array}$ \\
\hline
\end{tabular}

The possibility that the material was produced after death by autolytic processes was excluded by the fact that the proportion of hearts containing the material was the same, irrespective of the time interval since death; it occurred just as often in fresh as in decomposing bodies (Table). The occurrence of this material apparently does not indicate an ageing process, though the replacement of glycogen by a mucopolysaccharide in the autonomic ganglia of senile dogs and man has been described (Bourne, 1956). The proportion of hearts containing the material remained almost constant at any decade of life except at the extreme limits of youth and old age (Fig. 2).

Conducting tissues affected by chronic pathological processes, such as fibrosis or fatty infiltra- tion, did not show a greater incidence of the material than did anatomically normal tissues. Nor was its occurrence related to any particular form of death, it being as common in hearts from healthy persons dying as a result of some accident as in hearts from those who died of heart disease.

\section{CoNCLUSION}

The relatively high concentration of glycogen in the conducting tissue of the heart is well known, and has formed the basis of a method for outlining macroscopically this tissue in hearts examined shortly after death (Otsuka and Hara, 1965). However, glycogen disappears after a short postmortem interval; it has been suggested that the vacuolated appearance of the cells of the conducting tissue may be an artefact produced by autolytic digestion, or by chemical solution of the glycogen during histological procedures.

This study has shown an additional constituent of the conducting tissue, namely a PAS positive, diastase resistant material. It is not an artefact produced during the preparation of the sections. It may be a glycoprotein or a protein-carbohydrate complex.
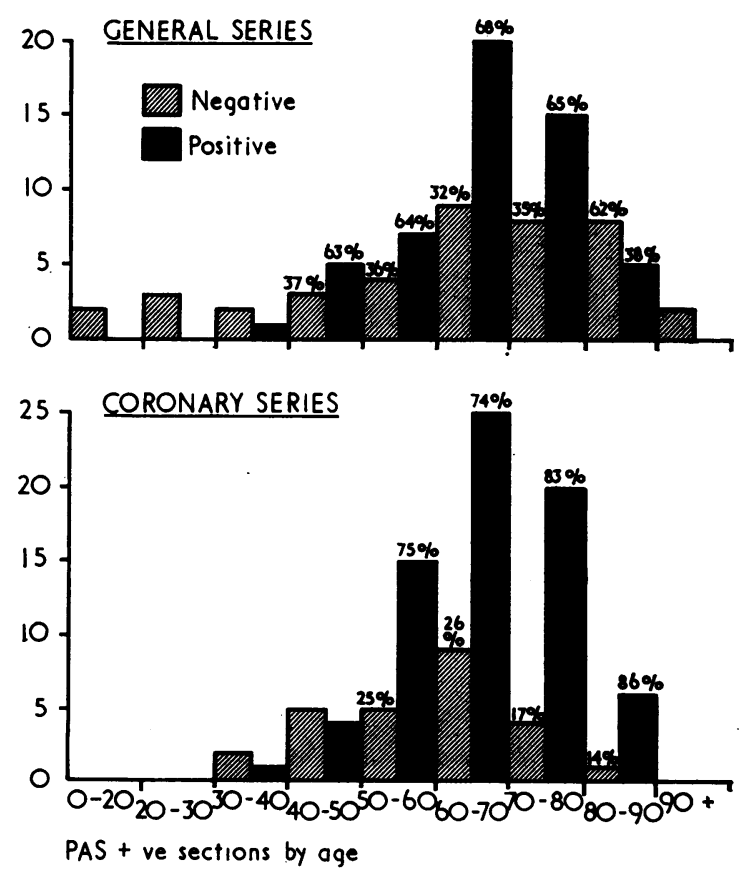

Fig. 2.-The age distribution of cases in the two series. Though more cases were examined during the middle years of life, the proportion of cases with the glycoprotein remained constant. 
The opinions of Professor R. E. B. Hudson and Professor A. G. E. Pearse have been sought with regard to the nature of the material. In Professor Pearse's view it may be a lipid or a lipid product, but is probably not predominantly protein because of the multigranular nature of the larger lumps. Unless of parasitic origin it must be an abnormal breakdown product, possibly a ceroid-like substance. Professor Hudson confirmed the presence of the material in his own collection of histological preparations.

The significance of the observation has yet to be determined; it may have some bearing on the function of the tissue.
I wish to thank Professors R. E. B. Hudson, A. G. E. Pearse, and C. J. Polson for their help and advice. I am also grateful to Mr. $\mathrm{H}$. Battison for preparation of the histological material, and Mr. H. G. Lumby for producing Fig. 2.

\section{REFERENCES}

Bourne, G. H. (1956). Ageing from a biological and cellular point of view. In Modern Trends in Geriatrics, chap. 2, p. 29. Ed. by William Hobson. Butterworth, London. Lumb, G., and Shacklett, R. S. (1960). Human cardiac conduction tissue lesions. Amer. F. Path., 36, 411.

Otsuka, N., and Hara, T. (1965). Gross demonstration of the mammalian atroventricular bundle by a periodic acid-Schiff procedure. Stain Technol., 40, 305.

Pearse, A. G. Everson (1960). Carbohydrates. In Histochemistry, 2nd ed., chap. 9, p. 238. Churchill, London. 